\title{
PENGARUH PRODUKSI UJARAN TERHADAP PEMEROLEHAN BAHASA PADA ANAK :SUATU KAJIAN NEUROPSIKOLINGUISTIK
}

\author{
Rika Kartika, Rita dan Ratna Soraya \\ Universitas Islam Sumatera Utara \\ rikakartika@fkip.uisu.ac.id
}

\begin{abstract}
Abstrak. Tujuan pembahasan dalam penelitian yang berjudul Pengaruh produksi ujaran terhadap pemerolehan bahasa pada anak adalah mendeskripsikan Pengaruh produksi ujaran terhadap pemerolehan bahasa pada anak. Jenis penelitian ini menggunakan metode kualitatif dengan teknik dokumentasi, observasi, dan wawancara.Teknik dokumentasi digunakan untuk mengumpulkan data tentang Pengaruh produksi ujaran terhadap pemerolehan bahasa pada anak. Hasil pembahasan di dapat adalah pengaruh produksi ujaran terhadap pemerolehan bahasa pada anak sangat berdampak baik terhadap anak dengan mengajarkan langkah-langkah yang dijelaskan maka anak dapat memproduksi ujarannya dengan baik sehingga anak nantinya dapat berbicara dengan lancar dan dapat memahami makna yang diucapkan oleh seseorang tersebut.
\end{abstract}

Kata Kunci: Produksi ujaran, pemerolehan bahasa, neoropsikolingusitik

\begin{abstract}
The purpose of the discussion in the study entitled The effect of speech production on language acquisition in children is to describe the effect of speech production on language acquisition in children. This type of research uses qualitative methods with documentation, observation, and interview techniques. Documentation techniques are used to collect data about the effect of speech production on language acquisition in children. The results of the discussion can be the effect of speech production on language acquisition in children has a very good impact on children by teaching the steps described so that children can produce their utterances well so that later children can speak fluently and understand the meaning spoken by someone.
\end{abstract}

Keywords: speech production, language acquisition, neoropsycholingusitic

\section{PENDAHULUAN}

Bahasa merupakan sistem tanda bunyi yang arbitrer dan telah disepakati serta dipergunakan oleh para anggota kelompok masyarakat tertentu dalam bekerja sama, berkomunikasi, dan mengidentifikasi diri. Dalam hal ini, kelompok masyarakat 'tertentu' yang dimaksud adalah satu kesatuan masyarakat dalam suatu wilayah yang memiliki pemahaman bersama terhadap bahasa yang digunakan sebagai alat komunikasi.

Salah satu faktor dalam diri manusia yang memiliki pengaruh besar dalam kegiatan berbahasa adalah sistem kerja otak. Sistem kerja otak memiliki pengaruh besar terhadap kegiatan berbahasa.
Besarnya pengaruh sistem kerja otak dalam kegiatan berbahasa karena otak merupakan sentral dari seluruh kegiatan tubuh manusia. Oleh karena itu, jika sistem kerja otak terganggu, maka otomatis kegiatan berbahasa juga terganggu.

Pada umumnya manusia berkomunikasi melalui bahasa dengan cara menulis atau berbicara. Jika komunikasi dilakukan dengan menulis, maka tidak alat ucap yang ikut terlibat di dalamnya. Sebaliknya, jika komunikasi dilakukan melalui berbicara, alat ucaplah yang memegang peranan penting. Alat ucap inilah yang nantinya menghasilkan bunyi bahasa. 
Bunyi bahasa merupakan hasil yang dibuat oleh alat ucap menusia seperti, pita suara, lidah, dan bibir. Bunyi bahasab) dibuat oleh manusi untuk mengungkapkanc) sesuatu. Bunyi bahasa ini dapat terwujud dalm nyanyian atau dalam tuturan.

Dalam berkomunikasi terdapat suatu proses yang harus dilakukan oleh individu yakni proses memroduksi ujaran. Dalam berkomunikasi seorang individu membutuhkan mental, proses mental ini menyangkut beberapa aspek. Aspek pertama berkaitan dengan asumsi individu tentang pengetahuan interlokutor dan aspek kedua adalah kooperatif.

Banyak langkah-langkah yang harus dilalui dalam memroduksi ujaran. Langkah-langkah tersebut di antaranya bisa berupa cara memroduksi konstituen, kalimat dan wacana. Dengan adanya langkah-langkah yang harus dilalui dalam memroduksi ujaran pada anak.

Berdasarkan penjelasan tersebut maka penulis membuat sebuah penelitian yang berjudul Pengaruh produksi ujaran terhadap pemerolehan bahasa pada anak :suatu kajian neuropsikolinguistik.

\section{METODE PENELITIAN}

Jenis penelitian ini menggunakan metode kualitatif dengan teknik dokumentasi, observasi, dan wawancara.Teknik dokumentasi digunakan untuk mengumpulkan data tentang Pengaruh produksi ujaran terhadap pemerolehan bahasa pada anak..

Pengumpulan data dengan metode dokumentasi dilakukan dengan data rekaman Pengaruh produksi ujaran terhadap pemerolehan bahasa pada anak .Teknik wawancara dilakukan untuk mengajarkan produksi bahasa pada anak pada usia 1 tahun sehingga ank terbiasa untuk berbicara dengan baik.

\section{PEMBAHASAN}

a) Pengertian Poduksi Bahasa/Ujaran

Secara bahasa produksi diartikan sebagai proses mengeluarkan hasil ataupenghasilan, sedangkan menurut Hornby, A.S production/produksi adalah kegiatan atau proses membuat sesuatu secara alami. Sedangkan ujaran yaitu perkataan yg diucapkan. Jadi produksi Ujaran adalah Proses yang menghasilakan perkataan.

\section{Langkah Umum Dalam Memproduksi Ujaran}

Djardjowidjojo mendefinisikan, "Proses dalam memproduksi ujaran dapat dibagi menjadi empat tingkat:

1. Tingkat pesan, di mana pesan yang akan disampaikan diproses,

2. Tingkat fungsional, di mana bentuk leksikal dipilih kemudian diberi peran dan fungsi sintaktik,

3. Tingkat posisional, di mana konstituen dibentuk dan afiksasi dilakukan, dan

4. Tingkat filologi, di mana struktur fonologi ujaran itu diwujudkan.

Pada tingkat pesan, pembicara mengumpulkan nosi-nosi dari makna yang ingin disampaikan. Sebagaimana contoh di bawah ini:

Contoh :"Ani sedang meny
anaknya" pembicaraan antara lain;

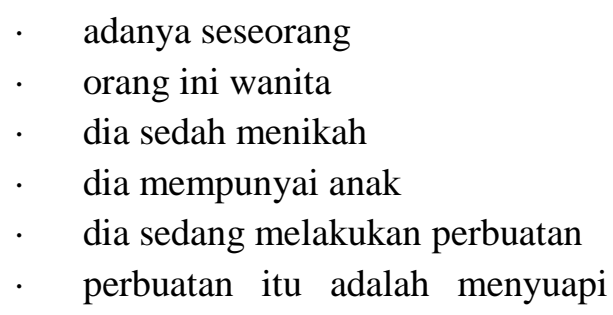

Pada tingkat fungsional, yang diproses ada dua hal. Pertama, memilih bentuk leksikal yang sesuai dengan pesan yang akan disampaikan dan informasi gramatikal untuk masing-masing yang dia kenal, wanita yang dimaksud adalah Tutiek, dan kata ini adalah nama orang perempuan; perbuatan yang dilakukan diwakili oleh verba dasar suap; antara argument ani dan anaknya, ani kadalah pelaku perbuatan sedang anaknya adalah resipiennya.

Proses kedua pada tingkat fungsional adalah memberikan fungsi pada kata yang telah dipilih. Proses di sini menyangkut hubungan sintaktik gramatikal atau fungsi gramatikal. Pada contoh diatas, kata ani harus dikaitkan dengan fungsi subjek sedangkan anaknya pada objek. Pada bahasa-bahasa tertentu, seperti Jerman fungsi-fungsi ini dimarkahi oleh kasuskasus khusus seperti kasus normative dan kasus objektif. Kata dia (pria), misalnya, adalah kasus eruntuk kasus normatif tetapi menjadi ihn untuk kasus objektif. 
Pada tingkat pemrosesan posisisonal, diurutkan bentuk leksikal untuk ujaran yang akan dikeluarkan. Pengurutan bentuk leksikal untuk ujaran yang akan dikeluarkan. Pengurutan ini bukan berdasarkan pada jejeran yang linear tetapi pada kesatuan makna yang hierarkhis. Pada contoh tersebut, katasedang bertaut dengan anak, dan bukan pada Ani atau menyuapi. Hierarki konstituen inilah yang menjadi dasar diagram pohon.

Setelah pengurutan selesai, diproseslah afiksasi yang relavan. Pada bahasa Indo-Eropa seperti bahasa Inggris, verba menyuapi (to feed) untuk kalimat tersebut haruslah mendapatkan afiks infleksional ing (feeding). Untuk bahasa Indonesia, verba dasar suap harus ditambah dengan suffix $-i$ (di samping perfiks $m e N$-secara opsional).

Hasil dari pemrosesan posisional ini "dikirim" ke tingkat fonologi untuk diwujudkan dalam bentuk bunyi. Pada tahap ini aturan fonotaktik bahasa Indonesia, tetapi ani tidak. Kata ini tentunya ditolak. Begitu juga vocal /u/ dan /i/ harus berurutan seperti itu karena kalau dibalik, Ani, referennya akan lain. Proses fonologis ini tidak sederhana kaena tersangkut pula di sini proses biologis neurologis.

\section{Rincian Produksi Ujaran}

Saat memproduksi ujaran, seseorang akan mulai merencanakan yang berkaitan dengan topik yang akan diujarkan, kemudian turun ke kalimat yang akan dipakai, dan diturunkan kembali ke konstituen yang akan dipilih. Setelah itu, barulah dia masuk ke pelaksanaan dari yang akan diujarkan.

Hal ini mencakup rencana artikulasi dan bagaimana mengartikulasikannya. Clark dan Clark mendefinisikan prosedur ini, sebagaimana dikutip Djarwowidjodjo, sebagaimana di bawah ini:

\section{Perencanaan Produksi Wacana}

Wacana dibagi menjadi dua macam dialog dan monolog. Perbedaan utama antara dua macam ini terutama terletak pada tindak interaksi antara pembicara dengan pendengar. Pada dialog terdapat paling tidak dua pelaku, yakni yang berbicara dan yang diajak bicara, interlokutornya. Pada wacana monolog hanya terdapat satu pelaku saja. Kalau wacana itu lisan, hanya ada satu pembicara; kalau wacana tulis, hanya penulis sebagai pelakunya.

Wacana tertulis disamping menempati ruang juga disusun dan dibaca pada saat-saat tertentu dalam waktu. Dimensi waktu serupa diberikan pada teks lisan melalui tindak pemroduksian teks oleh penutur dan tindak penerimaan teks oleh mitra tutur dalam waktu khusus.

\section{Perencanaan Produksi Kalimat}

Menurut Clark, sebagaimana dikutip oleh Dardjowidjojo, terdapat tiga kategori yang perlu diproses: muatan proposional (prpotional content), muatan ilokusioner dan struktur tematik.

Pada muatan proposional pembaca akan mendapatkan pembicara menentukan proposisi apa yang ingin dia nyatakan. Sedangkan pada muatan ilokusioner adalah makna yang akan diwujudkan itu seperti apa. Di sinilah peran tindak ujar muncul. Kemudian pada struktur tematik berkaitan dengan penentuan berbagai unsur dalam kaitannya dengan fungsi gramatikal atau semantik dalam kalimat.

\section{Perencanaan}

Produksi

\section{Konstituen}

Setelah perencanaan kalimat selesai dibuat, maka beralihlah pembicara pada tataran konstituen yang membentuk kalimat tersebut. Di sinilah dipilihnya kata yang maknanya tepat seperti yang dikehendaki. Seandainya referennya adalah seorang pria, maka kalau dia suka dengan orang tersebut, maka pilihlah kata si rajin atau ustazd. Sebaliknya, jika pembicara dalah pembenci pria, yang mungkin dipilihnya adalah si pemalas. Dengan demikian, kalimat di bawah (a) dan (b) merujuk pada referen yang sama.

Tuh, si rajin duduk 


\section{Tuh, si malas duduk.}

\section{Program Artikulasi}

Saat kata dipilih, kata tersebut dibentuk menjadi suatu "program artikulatori" dalam memori "buffer/penyangga" yang dapat merangkum semua kata konstituen yang direncanakan sekaligus. Hal ini mengandung representasi bagianbagian fonetik, tekanan/stress, dan pola intonasi yang dieksekusi pada langkah selanjutnya

\section{Artikulasi}

Langkah terakhir adalah mengeksekusi isi program artikulatori. Hal ini dilakukan dengan mekanisme dengan membahkan rangkaian dan ketepatan program artikulatori, mengarahkan otot-otok artikulatori apa yang harus dilakukan kemudian. Langkah ini menghasilkan bunyi yang dapat didengar, yaitu percakapan yang diinginkan.

Hal yang perlu diperhatikan kesalahan pemahaman bahwa berbicara merupakan kebalikan dari proses mendengar semata. Hubungan proses antara keduanya: dalam berbicara, makna diubah menjadi bunyi dan dalam mendengar bunyi diubah menjadi makna. Perbedaanya, dalam hal suara, berbicara memerlukan aktivasi motorik organorgan bicara, sedangkan mendengar merupakan analisa tanda-tanda bicara. Kedua aktivitas ini melibatkan organorgan yang berbeda. Dalam hal makna, ketika berbicara, si penutur mulai dengan niat mempengaruhi pendengar dan mengubah niat ini menjadi rencana pengucapan, sedangkan ketika mendengarkan, si pendengar mengenali rencana si penutur dan menyimpulkan niat si penutur tersebut.

\section{HASIL PEMBAHASAN}

Bahasa merupakan sistem tanda bunyi yang arbitrer dan telah disepakati serta dipergunakan oleh para anggota kelompok masyarakat tertentu dalam bekerja sama, berkomunikasi, dan mengidentifikasi diri. Dalam hal ini, kelompok masyarakat 'tertentu' yang dimaksud adalah satu kesatuan masyarakat dalam suatu wilayah yang memiliki pemahaman bersama terhadap bahasa yang digunakan sebagai alat komunikasi.

Production/produksi

adalah kegiatan atau proses membuat sesuatu secara alami. Sedangkan ujaran yaitu perkataan yg diucapkan. Jadi produksi Ujaran adalah Proses yang menghasilakan perkataan. langkah-langkah yang harus dilalui dalam memroduksi ujaran. Langkahlangkah tersebut di antaranya bisa berupa cara memroduksi konstituen, kalimat dan wacana. Dengan adanya langkah-langkah yang harus dilalui dalam memroduksi ujaran pada anak.

Pemerolehan bahasa adalah suatu proses yang digunakan oleh anakaanak untuk menyesuaikan serangkaian hipotesis yang bertambah rumit, atupun teori-teori yang masih terpendam atau tersembunyi yang mungkin sekali terjadi dengan ucapan -ucapan orang tuanya sampai dia memilih berdasarkan suatu ukuran atau takaran penilaian tatabahasa yang paling baik serta yang paling sederhana dari bahasa tersebut.

Dalam hal ini Pengaruh produksi ujaran terhadap pemerolehan bahasa pada anak sangat berdampak baik terhadap anak dengan mengajarkan langkah-langkah yang dijelaskan maka anak dapat memproduksi ujarannya dengan baik sehingga anak nantinya dapat berbicara dengan lancer dan dapat memahami makna yang diucapkan oleh seseorang tersebut.

\section{SIMPULAN}

Bahasa merupakan sistem tanda bunyi yang arbitrer dan telah disepakati serta dipergunakan oleh para anggota kelompok masyarakat tertentu dalam bekerja sama, berkomunikasi, dan mengidentifikasi diri. Dalam hal ini, kelompok masyarakat 'tertentu' yang dimaksud adalah satu kesatuan masyarakat dalam suatu wilayah yang memiliki pemahaman bersama terhadap bahasa yang digunakan sebagai alat komunikasi.

Secara bahasa produksi diartikan sebagai proses mengeluarkan hasil ataupenghasilan, sedangkan menurut Hornby, A.S production/produksi 
adalah kegiatan atau proses membuat sesuatu secara alami. Sedangkan ujaran yaitu perkataan yg diucapkan. Jadi produksi Ujaran adalah Proses yang menghasilakan perkataan.

Banyak langkah-langkah yang harus dilalui dalam memroduksi ujaran. Langkah-langkah tersebut di antaranya bisa berupa cara memroduksi konstituen, kalimat dan wacana. Dengan adanya langkah-langkah yang harus dilalui dalam memroduksi ujaran pada anak.

Pemerolehan bahasa adalah suatu proses yang digunakan oleh anak-anak untuk menyesuaikan serangkaian hipotesis yang bertambah rumit, atupun teori-teori yang masih terpendam atau tersembunyi yang mungkin sekali terjadi dengan ucapan -ucapan orang tuanya sampai dia memilih berdasarkan suatu ukuran atau takaran penilaian tatabahasa yang paling baik serta yang paling sederhana dari bahasa tersebut.

Dalam hal ini Pengaruh produksi ujaran terhadap pemerolehan bahasa pada anak sangat berdampak baik terhadap anak dengan mengajarkan langkah-langkah yang dijelaskan maka anak dapat memproduksi ujarannya dengan baik sehingga anak nantinya dapat berbicara dengan lancar dan dapat memahami makna yang diucapkan oleh seseorang tersebut.

\section{SARAN}

Berdasakan penjelasan di atas tentang Pengaruh produksi ujaran terhadap pemerolehan bahasa pada anak :suatu kajian neuropsikolinguistik saran yang dapat diberikan adalah sebagai berikut:

\section{Mahasiswa}

Mahasiswa dapat memahami materi ini untuk dapat menerapkan dalam kehidupan sehari hari serta dapat mengetahui Pengaruh produksi ujaran terhadap pemerolehan bahasa pada anak :suatu kajian neuropsikolinguistik dan dapat dijadikan sumber dalam mengambil mata kuliah neuropsikolinguistik.

2. Peneliti lanjutan

Bagi peneliti selanjutnya dapat menggunakan materi ini sebagai bahan referensi atau sumber informasi untuk melakukan penelitian selanjutnya.

\section{DAFTAR PUSTAKA}

Arifuddin. 2013. Neuropsikolinguistik. Jakarta: Rajawali Pers.

Djardjowidjojo,Soejono.2010. Psikolingui stik: Pengantar Pemahaman Manusia. Jakarta: Yayasan Obor Indonesia.

Louise Cumming. 2007. Pragmatik: Sebuah Perspektif Multidisipliner. Yogyakarta: Pustaka Pelajar.

Soejono Djardjowidjojo.

2003. Psikolinguistik:

Pengantar Pemahaman

Louise Cumming.

2007. Pragmatik: Sebuah

Perspektif

Multidisipliner. (Yogyakarta:

Pustaka Pelajar). 